\title{
Combining Ability for Nitrogen Use Efficiency in a Diallel Cross of Indian Rapeseed (Brassica rapa L.)
}

\author{
Priyakshee Borpatra Gohain ${ }^{1}$, Smrita Gogoi ${ }^{1}$, Kaushik Das ${ }^{2}$ and Purna K. Barua ${ }^{1}$. \\ ${ }^{1}$ Department of Plant Breeding and Genetics, Assam Agricultural University, \\ Jorhat-785013, India \\ ${ }^{2}$ Department of Crop Physiology, Assam Agricultural University, Jorhat, India \\ *Corresponding author
}

\section{Keywords}

Rapeseed, Brassica rapa, Nitrogen use efficiency, Combining ability, Heritability

\section{Article Info}

Accepted:

14 November 2020 Available Online:

10 December 2020

\section{A B S T R A C T}

Genetic variation, combining ability and character relationships among yield attributing characters including nitrogen use efficiency were evaluated at two levels of $\mathrm{N}$ fertilization in a diallel cross of Indian rapeseed. Three toria (TS-38, JT 90-1, TS-67) and three yellow sarson parents (NRCYS 05-03, YSH 401, B9) and their diallel $\mathrm{F}_{1} \mathrm{~s}$ excluding reciprocals were evaluated at 0 and $60 \mathrm{~kg} \mathrm{~N} / \mathrm{ha}$ during Rabi 2012-13. Variation between $\mathrm{N}$ levels was significant. Genotypes x N interactions were significant for some characters including seed and biological yield per plant. High to moderate genetic variation, high broad sense heritability and high genetic advance were recorded for nitrate reductase activity. Pooled analysis of combining ability exhibited significant variation in gca and sca effects for most of the characters. Interactions of gca and sca with $\mathrm{N}$ levels were observed only for a few characters. YSH 401 was the best general combiner for morpho-physiological yield attributes while JT 90-1 was the best general combiner for seed yield per ha. Seed yield per plant was positively correlated with biological yield and NUE at $\mathrm{N}_{60}$. Nitrogen use efficiency was highly heritable with high genetic variation and genetic advance. TS-38 was the best parent for mean performance and gca effect for NUE. Among the crosses, JT 90-1 x YSH 401 and YSH $401 \times$ B9 showed high mean performance and sca effects.

\section{Introduction}

The family Brassicaceae, containing about 350 genera and 3500 species, is one of the ten most economically important plant families with a wide range of agronomic traits (Christopher et al., 2005). Among the seven edible oilseeds cultivated in India, rapeseed- 
mustard ranks second after soybean. In Assam, it is the most important oilseed crop. However, productivity of rapeseed-mustard in Assam is very low compared to all India average. Therefore, serious efforts are necessary to achieve high seed yield through breeding high yielding varieties, agronomic management, plant protection measures etc.

Nitrogenous fertilizer is one of the most critical inputs that define crop productivity, and it must be supplemented to meet the demand of food production for an ever increasing population. To improve the sustainability of many crop species nitrogen use efficiency can be modified which is an important breeding trait in agriculture. Rapeseed production is highly dependent on nitrogen input. It is a major oilseed crop with low nitrogen use efficiency (Bouchet et al., 2016). Therefore, identification of appropriate genotypes for improvement of NUE is an important task. Adequate nutrient supply increases the seed and oil yields by improving yield attributing characters. Therefore, further improvement of nutrient use efficiency may contribute substantially towards seed yield.

Toria is the most important oilseed crop of Assam, accounting for about 90 percent of the state's oilseeds area. Emphasis is generally given to develop toria plant type by combining desirable high yielding characters of yellow sarson with high nutrient use efficiency for growing under rainfed cultivation. Genetic variation in toria x yellow sarson crosses was utilized in breeding toria varieties such as JT 90-1 (Barua, 2012, unpublished). However, the potential variation in toria $\mathrm{x}$ sarson crosses has not been sufficiently exploited. In view of the above, the present investigation was undertaken to study combining ability for NUE and character interrelationship between yield attributing characters including nitrogen use efficiency in a diallel cross involving toria and yellow sarson parents.

\section{Materials and Methods}

The investigation was carried out at the experimental farm of the Department of Plant Breeding and Genetics, Assam Agricultural University, Jorhat. The experimental materials were selected based on preliminary study on seed yield and nitrate reductase activity and comprised of three genotypes of toria (TS-38, JT 90-1, TS-67) and three of yellow sarson (NRCYS 05-03, YSH 401, B 9) were crossed in diallel design excluding the reciprocals during Rabi 2011-12. During Rabi 2012-13 the twenty one entries including parents and $F_{1} s$ were grown in randomized block design with two replications over two doses of nitrogen fertilizer i.e. $0 \mathrm{~kg} \mathrm{~N} /$ ha and $60 \mathrm{~kg} \mathrm{~N} / \mathrm{ha}$. Well decomposed cow dung manure @ $2 \mathrm{t} / \mathrm{ha}$ along with $40 \mathrm{~kg} \mathrm{P}_{2} \mathrm{O}_{5}$ and $25 \mathrm{~kg} \mathrm{~K} 2 \mathrm{O}$ per hectare were applied. Borax was applied @ $10 \mathrm{~kg} / \mathrm{ha}$. Each plot contained two rows measuring $3 \mathrm{~m}$ in length. Row to row spacing was $50 \mathrm{~cm}$, and plant spacing within row was adjusted to about $10 \mathrm{~cm}$ by thinning at seedling stage.To ascertain the fertility status of the soil in the experimental site representative sample from the top soil (0-20 cm depth) was collected from ten random spots for analysis of nutrient status. The soils were strongly acidic $\left(\mathrm{p}^{\mathrm{H}}\right.$ 5.44), available nitrogen $(192.03 \mathrm{~kg} / \mathrm{ha})$ was low, available phosphorus $(26.43 \mathrm{~kg} / \mathrm{ha})$ medium and available potassium $(68.04 \mathrm{~kg} / \mathrm{ha})$ was low.

Observations were recorded for six characters. Total leaf chlorophyll content (CHL) (mg $\mathrm{g}^{-1} \mathrm{FW}$ ) was extracted by nonmaceration method using dimethyl sulphoxide (Hiscox and Israelstam, 1979) and light absorption at $663 \mathrm{~nm}$ and $645 \mathrm{~nm}$ was read in a spectrophotometer. The amount of chlorophyll content was calculated using absorption coefficients. In vivo nitrate reductase activity (NRA) ( $\mu \mathrm{mol} \quad \mathrm{NO}_{2}{ }^{-} \mathrm{g}^{-1}$ $\mathrm{FWhr}^{-1}$ ) was estimated by spectrophotometer 
(Chemito, Model UV 2100) at $540 \mathrm{~nm}$ (Klepper and Hageman, 1969). For longest root length (LRL) roots of 10 sampled plants per plot were dug out carefully at harvest (Sirohiet al., 1978). Root volume (RV) was determined by water displacement method following Raja and Bishnoi (1990) and expressed in cc. Biological yield per plant (BYP) of the sampled plants was recorded bytaking dry weight of the above ground parts at harvest. Biological yield was calculated by summing up the weights of seeds and all other plant parts on per plant basis. Seed yield per plant (SYP) of each sampled plant was recorded in gram. Seed yield per plot was recorded including that of the sampled plants and converted to yield per ha. Based on that nitrogen use efficiency (NUE) was calculated as agronomic efficiency by using the following formula (Fageria and Baligar, 2005).

Nitrogen use efficiency (NUE) $\mathrm{kg} / \mathrm{kg}=\left(\mathrm{G}_{\mathrm{f}}-\right.$ $\mathrm{G}_{\mathrm{u}} / \mathrm{N}_{\mathrm{a}}$ )

Where $G_{f}$ is the seed yield per ha at $60 \mathrm{~kg}$ $\mathrm{N} / \mathrm{ha}, \mathrm{G}_{\mathrm{u}}$ is the seed yield per ha at $0 \mathrm{~kg} \mathrm{~N} / \mathrm{ha}$, and $\mathrm{N}_{\mathrm{a}}$ is the quantity of nitrogen applied, i.e. $60 \mathrm{~kg} / \mathrm{ha}$.

The plot mean values for each character were subjected to statistical and biometrical analyses. Pooled analysis of variance was performed following Gomez and Gomez (1984). Genotypic variances $\left(\sigma_{\mathrm{g}}^{2}\right)$, phenotypic variance $\left(\sigma_{\mathrm{p}}^{2}\right)$ and environmental variance $\left(\sigma_{\mathrm{e}}^{2}\right)$ were computed according to Singh (1973) in fixed model from the pooled ANOVA. Genotypic coefficient of variation (GCV), heritability $\left(\mathrm{h}^{2}\right)$ in broad sense and the expected genetic advance at 5 percent selection intensity were calculated following Allard (1960). Genetic advance was then expressed as percentage of the grand mean. Combining ability analysis of the half diallel population was done following model I, method 2 of Griffing (1956). Then a pooled analysis over environments was carried out according to the method given by Singh (1973, 1979). General combining ability and specific combining ability effects were estimated from the pooled analysis. Genotypic correlation coefficients between characters were computed with the help of the formula given by Al-Jibouri et al., (1958). Significance of correlation coefficients was tested by comparing with table values.

\section{Results and Discussion}

Pooled analysis of variance was done to assess the genotypic variation and genotypeenvironment interactions (Table 1). Difference between the two $\mathrm{N}$ levels was highly significant for all the characters. Application of nitrogen fertilizer $\left(\begin{array}{ll}\mathrm{N}_{6} & 0\end{array}\right)$ enhanced the expression of most of the plant characters leading to higher growth and yield of the crop than without N. The genotypes, parents and crosses differed significantly for all the characters, indicating existence of good amount of genetic variation in the materials. Average differences between the parents and the crosses were significant for root volume and nitrogen use efficiency. This implied that average heterosis in the crosses was significant for these two traits. Genotypeenvironment interactions were significant for longest root length, total chlorophyll content, biological and seed yield per plant.

\section{Genetic variability parameters}

Genotypic coefficient of variation, heritability in broad sense and expected genetic advance as percentage of mean were obtained from the pooled analysis of variance. GCV values $0-10$ percent was categorized as low, 10-20 percent as medium and more than 20 percent as high. Heritability values less than 60 percent was categorized as low, $60-80$ percent as moderate and more than 80 percent as high. 
Percent genetic advance less than 20 percent was categorized as low, 20-30 percent as moderate and more than 30 percent as high. The genotypic coefficient of variation was high for nitrogen use efficiency and nitrate reductase activity, moderate for root volume, total chlorophyll content, biological yield per plant and seed yield per plant (Table 2) whereas it was low for longest root length. Heritability in broad sense was high for root volume, NUE and nitrate reductase activity; moderate for chlorophyll content, longest root length and biological yield while it was low for seed yield per plant. High genetic advance was recorded for NUE, nitrate reductase activity, root volume, total chlorophyll content, and medium for biological yield per plant and yield per plant. High heritability coupled with high genetic advance is indicative of additive gene action for such characters. In the present study additive gene action was implied from high heritability and high genetic advance for NUE, nitrate reductase activity and root volume. For the other characters non-additive gene action was probably more important. This signified that there was a scope for improvement of NUE, NRA and root volume through selection. Earlier workers also reported similar observations for various yield attributes in rapeseed (Barman, 1994; Koch, 2005; Singh and Kumar, 2007). Rameeh (2010) observed high heritability for biological yield per plant. High heritability was also observed by Bouchet et al., (2016). Heritability is one of the important parameters that determine effectiveness of selection. However, heritability alone cannot indicate genetic progress in selection. Burton (1952) suggested that GCV together with heritability would give good indication of expected genetic advance. If high heritability is due to non-additive gene action genetic gain will be low; if it is due to additive gene action, expected gain in phenotypic selection will be high (Panse, 1957). High heritability estimates along with high expected genetic give an indication of additive or non-additive gene action from such genetic parameters. In the present study, high heritability along with high genetic advance was observed for root volume and nitrate reductase activity. Similar association of high heritability with high genetic advance for this character was also recorded by Koch (2005), Singh and Kumar (2007) and Misra (2012). It could be inferred that these characters were likely to be governed by additive gene action which could be capitalized through individual plant selection based on phenotype. $\mathrm{G} \times \mathrm{N}$ interactions were significant for total chlorophyll content, longest root length, biological yield per plant and seed yield per plant. Earlier findings of Barua (1992) and Sarma (1993) were in agreement with the present results except for seed yield. Rameeh (2010) found significant G x E interactions for seed yield per plant. However, no significant $\mathrm{G} \times \mathrm{N}$ effect was detected for NUE supported by Bouchet et al., (2016) and Stahl et al., (2019).

\section{Combining ability analysis}

Significant variation in general combining ability effects was observed for all the characters other than seed yield per plant (Table 3). Variation due to specific combining ability was significant for all characters except longest root length. For longest root length only gca mean squares were significant, indicating preponderance of additive gene effects for this trait. On the other hand, variation for seed yield per plant was due to only non-additive gene effects. It is observed that both GCA x N and SCA x N interactions were significant for longest root length, total chlorophyll content and seed yield per plant; whereas SCA x N interaction alone was significant for biological yield per plant. The gca effects were greater in magnitude than its interaction component for 
the most of the characters for which significant GCA $x \quad \mathrm{~N}$ interactions were observed. On the other hand, sca effects were greater in magnitude than its interaction component for longest root length, total chlorophyll content, biological yield per plant and seed yield per plant. These showed that gca and sca effects were sensitive to environmental variation. For NUE both GCA and SCA effects were highly significant (Table 3).

Analysis of variance for combining ability revealed that variation due to both gca and sca effects were significant for chlorophyll content, nitrate reductase activity, root volume, biological yield and nitrogen use efficiency. GCA:SCA variance ratio for these characters exhibited that gca was predominant for chlorophyll content, nitrate reductase activity and root volume, whereas predictability on the basis of gca was less emphatic for biological yield and nitrogen use efficiency. Rameeh (2017) reported prevalence of additive genes influencing most of the traits. Lal et al., (2018) reported importance of non-additive gene action in the expression of different characters in both timely and late sown conditions. For longest root length variance due to gca alone indicating the importance of only additive gene effects. In respect of seed yield per plant, only sca was found significant. Hence, the variation among the crosses was due to predominance of non-additive gene action for seed yield per plant. It signifies the presence of non-additive genetic effects for this trait and for that reason selection should be delayed to the later generations for improvement of seed yield and selection methods like biparental mating should be effective to exploit non-additive gene effects. Similar results were also reported earlier for seed yield per plant by Barua (1992), Nasim et al., (1997), Brar et al., (2006), Singh et al., (2010), Dar et al., (2010), Rahman et al.,
(2011), Meena et al., (2015), Naheed et al., (2017) and Channa et al., (2018).

Relative importance of gca and sca effects could be observed from the ratio of gca variance to total (gca and sca) variance (Baker, 1978). This ratio was worked out for each character and expressed as percentage (Table 3). This ratio was high for total chlorophyll content, nitrate reductase activity and root volume. For longest root length additive effect was only predominant. The ratio was medium for biological yield and low for nitrogen use efficiency. It indicates higher predictability of progeny performance based on gca, which is due to additive and additive $\mathrm{x}$ additive gene effects (Roy, 2012). Such gene effects can be fixed in the progenies by selection. Most of the studies showed significant gca and sca effects for yield and its components, indicating the importance of both additive and non-additive gene actions in the inheritance of these traits (Thurling and Das, 1979; Cheema and Sadaqat, 2004). Similar observations were also made by Barua (1992), Singh et al., (2001), Dar et al., (2010) and Rahman et al., (2011).

Heritability in narrow sense estimated from the combining ability analysis was high for nitrogen reductase activity, chlorophyll content, longest root length and root volume (Table 3). It was moderate for biological yield and NUE and low for seed yield per plant. Expected genetic advance was high for all the traits except seed yield.

\section{Combining ability effects and mean performance}

The potentiality of a strain to be used as a parent in hybridization programme could be judged by combining ability and per se performance. Per se performance of parents might give a reasonable indication of their gca effects (Venkateswarlu and Singh, 1981). For 
the characters NUE and biological yield per plant combining ability of the parents could be fairly judged from their per se performance. Barua (1992) and Ofori and Becker (2008) reported similar correspondence between per se performance and gca effects in rapeseed.

The estimation of general combining ability effects along with per se performance of the parents, pooled from the two levels of $\mathrm{N}$ are presented in Table 4. TS-38 was the best general combiner for NUE. It was the only parent showing significant positive gca effect with high mean for NUE $(36.27 \mathrm{~kg} / \mathrm{kg})$. JT901 exhibited high mean for nitrate reductase activity, chlorophyll content, root volume and seed yield per plant. It showed significant gca effect for seed yield. Its mean for NUE was high $(26.56 \mathrm{~kg} / \mathrm{kg})$ but significantly less than that of TS-38. TS-67 showed high mean for NRA and chlorophyll content. Its mean NUE was $20.81 \mathrm{~kg} / \mathrm{kg}$.

Among the yellow sarson parents NRCYS 0503 was a good combiner for root volume. It showed high mean performance for chlorophyll content, longest root length, root volume, biological and seed yield per plant. It was tall growing and late maturing variety with poor combining ability for NUE with low mean of $6.17 \mathrm{~kg} / \mathrm{kg}$. YSH 401 was the best general combiner for longest root length, nitrate reductase activity and biological yield per plant. Its NUE was low $(11.17 \mathrm{~kg} / \mathrm{kg})$. It showed high mean performance for NRA, chlorophyll content, root length, root volume and biological yield per plant. Besides, it was a good general combiner for total chlorophyll content also. Overall, it was the best parent having significant positive gca effects for several traits related to NUE. B9 was the best general combiner for nitrate reductase activity with high mean performance for this trait. It was also a good parent for total chlorophyll content, longest root length and root volume.
Its mean NUE was $17.71 \mathrm{~kg} / \mathrm{kg}$, which was less than the toria parents. Thus compared to yellow sarson parents the toria varieties were having higher NUE.

In the cross TS-38 x JT 90-1, significant sca effects were observed for nitrate reductase activity and root volume. TS-38 x TS-67 showed significant sca effects for total chlorophyll content. JT 90-1 x YSH 401 showed high mean performance for seed yield per plant. JT 90-1 x B9 showed significant sca effects for total chlorophyll content, longest root length, biological yield per plant and seed yield per plant. It also showed the highest mean performance for total chlorophyll content and relatively high values for all other characters. In TS-67 x NRCYS 05-03, significant sca effect was found for the character nitrate reductase activity. This cross showed the highest nitrate reductase activity. TS-67 x YSH 401 showed the significant sca effects for root volume, biological yield per plant and seed yield per plant. It exhibited high mean performance for root volume and seed yield per plant. TS-67 x B9 was a good cross in respect of root volume. This cross exhibited high mean performance for most of the characters. NRCYS 05-03 x YSH 401 showed significant sca effects for characters like nitrate reductase activity and root volume. NRCYS 05-03 x B9 showed significant sca effects for nitrate reductase activity, total chlorophyll content and root volume with the highest mean values for root volume. YSH 401 x B9 exhibited significant sca effects for root volume, biological yield per plant and seed yield per plant and the highest mean performance for biological yield per plant. Its mean performance for other characters was also high.

Crosses YSH 401 x B9 and TS-67 x YSH 401 showed significant sca effect for seed yield per plant along with high mean for seed yield per plant. The crosses showing high sca 
effects for yield per plant involved high $\mathrm{x}$ low gca parents. The good general combiners generally possess high additive effects and poor general combiners are often associated with non-additive gene effects. Thus, it can be inferred that high sca effects of crosses involving high $\mathrm{x}$ low gca might have resulted due to the interaction of additive and nonadditive components. This may be due to dominant $\mathrm{x}$ recessive interaction expected to produce desirable segregates. These findings were in agreement with the results of Sharma et al., (2008) in toria and Singh et al., (2010) in mustard.

Some other important cross combinations JT 90-1 x B9, NRCYS 05-03 x YSH401, TS-38 $x$ JT 90-1, NRCYS 05-03 x B9 and TS-67 x NRCYS 05-03 involved high $x$ high, low $x$ low and low $x$ high gca parents. In case of high $\mathrm{x}$ high crosses there was possibility of complementary epistatic effects acting in the direction of additive effects of good combiner and that low $\mathrm{x}$ low combiner might be due to duplicate type of epistasis.

\section{Genotypic correlations}

Being a complex quantitative trait, yield is influenced by different genetically controlled yield attributing plant characters. To understand the influence of these attributes on yield, it is necessary to study their association with yield and yield attributes at genotypic level. Genotypic correlation chiefly results from linkage, pleiotropic effects of genes and effects of selection either individually or jointly (Falconer, 1960). In the present study genetic correlation coefficients were computed between NUE and related traits at both the levels of $\mathrm{N}$ fertilization. At $\mathrm{N}_{0}$ none of the characters showed significant correlation with yield per plant (data not presented). Positive correlations were observed between biological yield per plant with longest root length and root volume. Root volume and longest root length were positively correlated at genotypic level and both these traits were positively correlated with chlorophyll content. Root volume was positively correlated with nitrate reductase activity. There was positive correlation between total chlorophyll content and nitrate reductase activity. At $\mathrm{N}_{60}$ (Table 6) seed yield per plant was positively correlated with biological yield per plant and nitrogen use efficiency. Positive correlations were observed for nitrogen use efficiency with biological yield. Biological yield per plant was positively correlated with total chlorophyll content, longest root length and root volume. Longest root length and root volume were positively correlated with each other, and both of them were positively correlated with nitrate reductase activity and total chlorophyll content. Thus, these characters can be regarded as important yield attributes. Nitrogen use efficiency and seed yield were highly positively interrelated. Similar results were reported by Stahl et al., (2019). Therefore, it might be possible to develop high yielding varieties possessing high nitrogen use efficiency.

Application of $\mathrm{N}$ fertilizer enormously influences growth and yield of crop plants. In general the brassica crops respond to $\mathrm{N}$ fertilization very well. The plant architecture changes in response to applied N. As a result the character relationships are also altered. Homogeneity of the two sets of genotypic correlation coefficients were tested by chisquare. Significant chi-squares were found for correlations between seed yield per plant and biological yield per plant (Table 7). This indicated heterogeneity of genotypic correlation coefficients at $\mathrm{N}_{0}$ and $\mathrm{N}_{60}$. Heterogeneity of correlations was similarly observed for correlations nitrate reductase activity with chlorophyll content and longest root length. Thus it was observed that application of $\mathrm{N}$ fertilizers significantly altered the character relationships at genotypic level for certain characters. 
Table.1 Pooled analysis of variance of a diallel cross in Indian rapeseed

\begin{tabular}{|c|c|c|c|c|c|c|c|c|}
\hline Source & df & CHL & NRA & LRL & $\mathbf{R V}$ & BYP & SYP & $\mathbf{N U E}^{1}$ \\
\hline N levels & 1 & $554.22 * *$ & $0.141 * *$ & $87.40 * *$ & $39.02 * *$ & $5691.42 * *$ & $1300.94 * *$ & - \\
\hline Rep/N & 2 & 14.74 & 0.007 & 0.31 & 0.75 & 33.44 & $34.18^{*}$ & $69.63^{*}$ \\
\hline Genotypes & 20 & $63.14 * *$ & $0.037 * *$ & $4.42 * *$ & $23.30 * *$ & $272.11 * *$ & $35.41 * *$ & $166.38 * *$ \\
\hline Crosses & 14 & $61.55^{* *}$ & $0.045^{* *}$ & $4.63 * *$ & $23.16^{* *}$ & $305.46^{* *}$ & $34.86^{* *}$ & $82.81 * *$ \\
\hline Parents & 5 & $79.28 * *$ & $0.021^{*}$ & $4.62 * *$ & $18.60 * *$ & $222.64 * *$ & $43.91 * *$ & $233.36^{* *}$ \\
\hline P vs. C & 1 & 4.74 & 0.005 & 0.51 & $48.88 * *$ & 52.56 & 0.57 & $216.82 * *$ \\
\hline $\mathbf{G} \times \mathbf{N}$ & 20 & $15.80 * *$ & 0.005 & $1.39 * *$ & 1.48 & $133.98 *$ & $24.55^{* *}$ & - \\
\hline Pooled error & 40 & 6.12 & 0.006 & 0.45 & 1.46 & 67.23 & 7.18 & 11.67 \\
\hline CV\% & & 11.29 & 22.155 & 4.74 & 8.98 & 19.52 & 15.80 & 21.11 \\
\hline
\end{tabular}

${ }^{1}$ NUE was observed by combining the yields from both $\mathrm{N}$ levels

* Significant at $\mathrm{P}=0.05$ and ** Significant at $\mathrm{P}=0.01$

Table.2 Estimates of genetic parameters for various characters in Indian rapeseed from the pooled analysis

\begin{tabular}{|c|c|c|c|c|c|c|}
\hline Characters & Mean & $\pm \mathrm{SE}(\mathrm{m})$ & Range & GCV $(\%)$ & $\mathbf{h}^{2} \mathbf{b s}(\%)$ & GA (\%) \\
\hline Nitate reductase activity $\left(\mu \mathrm{molNO}{ }^{-} \mathrm{g}^{-1} \mathrm{FWhr}^{-1}\right)$ & 0.354 & 0.04 & $0.175-0.490$ & 24.69 & 83.24 & 46.40 \\
\hline Total chlorophyll content $\left(\mathrm{mgg}^{-1} \mathbf{F W}\right)$ & 0.219 & 1.24 & $0.128-0.268$ & 17.24 & 78.30 & 31.42 \\
\hline Longest root length $(\mathrm{cm})$ & 14.10 & 0.33 & $12.40-15.73$ & 7.07 & 74.16 & 12.55 \\
\hline Root volume (cc) & 13.44 & 0.60 & $9.55-17.76$ & 17.39 & 93.65 & 34.67 \\
\hline Biological yield per plant (g) & 41.96 & 4.10 & $23.08-55.02$ & 17.06 & 60.46 & 27.32 \\
\hline Seed yield per plant (g) & 16.87 & 1.33 & $12.86-22.40$ & 15.74 & 53.48 & 23.72 \\
\hline Nitrogen use efficiency $(\mathrm{kg} / \mathrm{kg})$ & 16.18 & 2.46 & $4.97-36.27$ & 46.86 & 90.45 & 91.80 \\
\hline
\end{tabular}


Table.3 Pooled analysis of variance of combining ability in a diallel cross of Indian rapeseed

\begin{tabular}{|l|l|l|l|l|l|l|l|l|}
\hline Source & df & CHL & NRA & LRL & RV & BYP & SYP & NUE \\
\hline GCA & 5 & $0.704^{* *}$ & $0.030^{* *}$ & $5.40^{* *}$ & $18.93^{* *}$ & $150.78^{* *}$ & 4.42 & $63.11^{* *}$ \\
\hline SCA & 15 & $0.186^{* *}$ & $0.014^{* *}$ & 1.15 & $9.23^{* *}$ & $131.15^{* *}$ & $22.13^{* *}$ & $63.73^{* *}$ \\
\hline N levels & 1 & $0.277^{* *}$ & $0.071^{* *}$ & $43.70^{* *}$ & $19.51^{* *}$ & $2845.71^{* *}$ & $650.47^{* *}$ & - \\
\hline GCA x N & 5 & 0.233 & 0.004 & 1.07 & 0.76 & 21.49 & $12.11^{*}$ & - \\
\hline SCA x N & 15 & $0.098^{* *}$ & 0.002 & 0.57 & 0.73 & $82.16^{*}$ & $12.33^{* *}$ & - \\
\hline Error & 40 & 0.031 & 0.003 & 0.22 & 0.73 & 33.61 & 3.59 & 6.07 \\
\hline G:S variance ratio & & 0.90 & 0.81 & - & 0.92 & 0.71 & - & 0.66 \\
\hline Heritability (ns) & & 87.85 & 79.03 & 89.99 & 79.78 & 64.12 & 7.00 & 64.16 \\
\hline Genetic advance (\%) & & 102.31 & 120.50 & 44.58 & 82.59 & 60.18 & 4.17 & 108.92 \\
\hline
\end{tabular}

${ }^{1}$ NUE was worked out by using data of both $\mathrm{N}_{0}$ and $\mathrm{N}_{60} \cdot *$ Significant at $\mathrm{P}=0.05$ and ** Significant at $\mathrm{P}=0.01$

Table.4 General combining ability effects and per se performance of the parental lines in Indian rapeseed

\begin{tabular}{|c|c|c|c|c|c|c|c|c|c|c|c|c|c|c|}
\hline \multirow[b]{2}{*}{ Parents } & \multicolumn{2}{|c|}{$\begin{array}{l}\text { NRA }(\mu \mathrm{mol} \\
\left.\text { NO }_{2}^{-} \mathbf{g}^{-1} \mathrm{FWh} \mathbf{r}^{-1}\right)\end{array}$} & \multicolumn{2}{|c|}{$\begin{array}{l}\text { CHL (x100) } \\
\left(\mathrm{mg} \mathrm{g}^{-1} \mathrm{FW}\right)\end{array}$} & \multicolumn{2}{|c|}{ LRL (cm) } & \multicolumn{2}{|c|}{ RV (cc) } & \multicolumn{2}{|c|}{ BYP (g) } & \multicolumn{2}{|c|}{ NUE (kg/kg) } & \multicolumn{2}{|c|}{ SYP (g) } \\
\hline & GCA & Mean & GCA & Mean & GCA & Mean & GCA & Mean & GCA & Mean & GCA & Mean & GCA & Mean \\
\hline TS-38 & $-0.09 * *$ & 0.24 & $-3.54 * *$ & 12.85 & $-0.57 * *$ & 13.36 & $-1.90 *$ & 9.18 & $-3.26^{*}$ & 46.48 & $1.90^{*}$ & 36.27 & $-1.34 * *$ & 19.67 \\
\hline JT 90-1 & 0.01 & 0.43 & -0.17 & 24.13 & $-0.34 * *$ & 13.81 & $-0.52 * *$ & 13.43 & $-3.47 * *$ & 36.00 & 1.23 & 26.56 & $0.96 *$ & 20.64 \\
\hline TS-67 & 0.01 & 0.39 & -0.67 & 22.28 & $-0.55^{* *}$ & 12.93 & 0.04 & 11.00 & -1.16 & 32.89 & -0.64 & 20.81 & -0.14 & 17.42 \\
\hline NRCYS 05-03 & -0.01 & 0.32 & 0.17 & 23.48 & 0.21 & 15.19 & $0.75 * *$ & 14.95 & 1.81 & 48.19 & $-5.44 * *$ & 6.17 & -0.04 & 19.84 \\
\hline YSH 401 & $0.03 * *$ & 0.42 & $2.29 * *$ & 25.07 & $0.87 * *$ & 15.73 & $1.09 * *$ & 13.75 & $3.89 * *$ & 47.62 & 1.37 & 11.13 & 0.63 & 15.95 \\
\hline B9 & $0.03 * *$ & 0.39 & $1.93 * *$ & 21.36 & $0.38 * *$ & 14.32 & $0.55 * *$ & 11.10 & 2.18 & 33.10 & 1.57 & 17.71 & -0.07 & 15.37 \\
\hline $\mathrm{SE}(\mathrm{gi}) / \mathrm{CD5} \%$ & 0.01 & 0.11 & 0.40 & 3.53 & 0.11 & 0.95 & 0.20 & 1.72 & 1.32 & 11.71 & 0.80 & 7.27 & 0.37 & 3.24 \\
\hline SE (gi-gj) & 0.02 & & 0.62 & & 0.17 & & 0.30 & & 2.05 & & 1.23 & & 0.57 & \\
\hline
\end{tabular}

* Significant at $\mathrm{P}=0.05 ; * *$ Significant at $\mathrm{P}=0.01$ 
Table.5(a) Specific combining ability effects, percent better parent heterosis and per se performance of the crosses in Indian rapeseed

\begin{tabular}{|c|c|c|c|c|c|c|c|c|}
\hline \multirow[t]{2}{*}{ Crosses } & \multicolumn{2}{|c|}{ NRA } & \multicolumn{2}{|c|}{ CHL (x100) } & \multicolumn{2}{|c|}{ RV (cc) } & \multicolumn{2}{|c|}{ LRL (cm) } \\
\hline & SCA & Mean & SCA & Mean & SCA & Mean & SCA & Mean \\
\hline TS 38 x JT90-1 & $0.079 * *$ & 0.360 & 1.51 & 19.70 & $1.92 * *$ & 12.95 & -0.116 & 13.07 \\
\hline TS $38 \times$ TS 67 & -0.034 & 0.240 & $1.85^{*}$ & 19.54 & 0.57 & 12.15 & $1.125^{* *}$ & 14.11 \\
\hline TS $38 \times$ NRCYS-05-03 & $-0.099 * *$ & 0.175 & -1.66 & 16.88 & -0.10 & 12.20 & $-0.621^{*}$ & 13.12 \\
\hline TS $38 \times$ YSH 401 & -0.057 & 0.241 & 0.97 & 21.62 & $-1.53 * *$ & 11.10 & $-0.984 * *$ & 13.41 \\
\hline TS 38 x B9 & -0.009 & 0.293 & 1.28 & 21.56 & 0.07 & 12.16 & -0.217 & 13.69 \\
\hline JT90-1 x TS 67 & -0.042 & 0.329 & $-5.91 * *$ & 15.15 & 0.21 & 13.17 & $-0.635^{*}$ & 12.58 \\
\hline JT90-1 x NRCYS-05-03 & $-0.123 * *$ & 0.248 & $-5.59 * *$ & 16.31 & $-4.12 * *$ & 9.55 & $-1.565 * *$ & 12.40 \\
\hline JT90-1 x YSH 401 & 0.046 & 0.442 & 1.74 & 25.76 & -0.03 & 13.98 & 0.408 & 15.03 \\
\hline JT90-1 x B9 & $-0.069 *$ & 0.331 & $3.11^{* *}$ & 26.77 & -0.05 & 13.41 & $1.115 * *$ & 15.25 \\
\hline TS 67 x NRCYS-05-03 & $0.126 * *$ & 0.490 & 1.12 & 22.52 & 0.00 & 14.23 & 0.084 & 13.85 \\
\hline TS 67 x YSH 401 & $-0.129 * *$ & 0.258 & -1.63 & 21.89 & $2.28 * *$ & 16.85 & 0.029 & 14.45 \\
\hline TS $67 \times$ B9 & 0.016 & 0.409 & 1.14 & 24.30 & $1.96^{* *}$ & 15.99 & -0.444 & 13.49 \\
\hline NRCYS-05-03 x YSH 401 & $0.097 * *$ & 0.485 & 1.08 & 25.44 & $1.15^{* *}$ & 16.43 & 0.457 & 15.64 \\
\hline NRCYS-05-03 x B9 & $0.096 * *$ & 0.489 & $2.59 * *$ & 26.59 & $3.03 * *$ & 17.76 & 0.312 & 15.00 \\
\hline YSH 401 x B9 & 0.031 & 0.448 & 0.67 & 26.79 & $1.85^{* *}$ & 16.93 & 0.317 & 15.67 \\
\hline SE (sij)/ CD5\% & 0.029 & 0.112 & 0.91 & 3.53 & 0.44 & 1.72 & 0.245 & 0.95 \\
\hline SE (sij-sik) & 0.052 & & 1.64 & & 0.80 & & 0.442 & \\
\hline SE (sij-skm) & 0.048 & & 1.51 & & 0.74 & & 0.409 & \\
\hline
\end{tabular}

* Significant at $\mathrm{P}=0.05$ and ** Significant at $\mathrm{P}=0.01$ 
Table.5(b) Specific combining ability effects, percent better parent heterosis and per se performance of the crosses in Indian rapeseed

\begin{tabular}{|c|c|c|c|c|c|c|}
\hline \multirow[t]{2}{*}{ Cross } & \multicolumn{2}{|c|}{ BYP $(g)$} & \multicolumn{2}{|c|}{ SYP $(g)$} & \multicolumn{2}{|c|}{ NUE (kg/kg) } \\
\hline & SCA & Mean & SCA & Mean & SCA & Mean \\
\hline TS 38 x JT90-1 & $-12.17 * *$ & 23.08 & $-4.44 * *$ & 12.86 & $-9.74 * *$ & 9.57 \\
\hline TS $38 \times$ TS 67 & -4.21 & 33.34 & $-2.30 *$ & 13.76 & $-6.51 * *$ & 10.94 \\
\hline TS $38 \times$ NRCYS05-03 & -6.78 & 33.74 & $-3.16^{* *}$ & 12.88 & $-5.98 * *$ & 6.67 \\
\hline TS 38 x YSH 401 & 0.15 & 42.75 & -1.87 & 15.11 & -1.36 & 18.09 \\
\hline TS 38 x B9 & 0.95 & 41.84 & -0.64 & 15.99 & $-8.98 * *$ & 10.68 \\
\hline JT90-1 x TS 67 & 2.64 & 39.98 & 0.16 & 17.33 & $-11.80 * *$ & 4.97 \\
\hline JT90-1 x NRCYS05-03 & 0.63 & 40.93 & -0.41 & 16.74 & -3.09 & 8.89 \\
\hline JT90-1 x YSH 401 & -5.25 & 37.14 & 1.20 & 19.29 & $7.10 * *$ & 25.89 \\
\hline JT90-1 x B9 & $12.22 * *$ & 52.90 & $4.20 * *$ & 21.94 & 1.69 & 20.68 \\
\hline TS $67 \times$ NRCYS05-03 & 3.67 & 46.28 & -0.72 & 15.18 & 1.90 & 12.01 \\
\hline TS 67 x YSH 401 & $9.66 * *$ & 54.36 & $5.08 * *$ & 21.93 & 0.17 & 17.08 \\
\hline TS 67 x B9 & 1.76 & 44.74 & -0.86 & 15.64 & 4.43 & 21.55 \\
\hline NRCYS-05-03 x YSH 401 & -7.29 & 40.38 & -0.01 & 16.81 & 4.52 & 16.64 \\
\hline NRCYS05-03 x B9 & 4.53 & 50.48 & 1.35 & 17.83 & 0.93 & 13.25 \\
\hline YSH 401 x B9 & $6.98 *$ & 55.02 & $3.19 * *$ & 20.60 & $5.17 *$ & 24.30 \\
\hline SE (sij)/ CD5\% & 3.00 & 11.71 & 0.98 & 3.83 & 2.14 & 7.13 \\
\hline SE (sij-sik) & 5.42 & & 1.77 & & 3.19 & \\
\hline SE (sij-skm) & 5.02 & & 1.64 & & 2.96 & \\
\hline
\end{tabular}

* Significant at $\mathrm{P}=0.05$ and ** Significant at $\mathrm{P}=0.01$ 
Table.6 Genotypic correlation coefficients between different characters in a diallel cross of Indian rapeseed at $60 \mathrm{~kg}$ N/ha

\begin{tabular}{|c|c|c|c|c|c|c|}
\hline & Chlorophyll & Longest root length & Root volume & Biological yield & NUE & Seed yield/plant \\
\hline NR activity & $0.91 * *$ & $0.71 * *$ & $0.83 * *$ & 0.36 & 0.07 & 0.13 \\
\hline Chlorophyll & & $0.69 * *$ & $0.69 * *$ & $0.69 * *$ & 0.22 & 0.31 \\
\hline Root length & & & $0.60 * *$ & $0.48 *$ & 0.08 & 0.23 \\
\hline Root volume & & & & $0.49 *$ & -0.12 & $0.64 * *$ \\
\hline Biological yield & & & & & $1.02 * *$ \\
\hline NUE & & & & & $0.93 * *$ \\
\hline
\end{tabular}

* Significant at $\mathrm{P}=0.05 ; *$ Significant at $\mathrm{P}=0.01$

Table 7 Chi-square values for test of homogeneity of genotypic correlation coefficients at two doses of $\mathrm{N}$ fertilizers in rapeseed

\begin{tabular}{|c|c|c|c|c|c|}
\hline & $\begin{array}{c}\text { Chlorophyll } \\
\text { content }\end{array}$ & $\begin{array}{l}\text { Longest root } \\
\text { length }\end{array}$ & Root volume & Biological yield & Seed yield/plant \\
\hline NR activity & $4.45^{*}$ & $3.96 *$ & 3.78 & 1.56 & 2.12 \\
\hline Chlorophyll content & & 0.20 & 0.00 & 1.90 & 1.83 \\
\hline Longest root length & & & 0.09 & 0.03 & 0.06 \\
\hline Root volume & & & & 0.06 & 0.02 \\
\hline Biological yield & & & & & $44.02 * *$ \\
\hline
\end{tabular}

* Significant at $\mathrm{P}=0.05 ; *$ Significant at $\mathrm{P}=0.01$ 
In conclusion, nitrogen use efficiency is a complex trait is suspected to be sensitive to genotype $\times$ environment interactions, especially genotype $\times$ nitrogen interactions. Therefore, phenotyping diverse rapeseed populations under a network of trials or in different environments is a powerful approach to study nitrogen use efficiency in this crop (Bouchet et al., 2016). There is strong evidence in the literature for substantial breeding progress enhancing oilseed rape $(B$. napus) yields under divergent $\mathrm{N}$ fertilization levels (Stahl et al., 2017). Due to increasing use of $\mathrm{N}$ fertilizers in the crop fields, necessary measures should be taken to minimize the leaching loss and adverse effects of accumulation of reactive $\mathrm{N}$ species in the environment. In the present analyses, NUE was found to be a highly heritable character with high genetic advance and high genetic variation in rapeseed genotypes. Thus, direct selection for this character would be fruitful. Combining ability analysis indicated the importance of additive and additive $\mathrm{x}$ additive type of gene action for NUE. Toria parent TS-38 was found as good general combiner for NUE. Yellow sarson parent YSH401 was also a good general combiner for traits related to NUE. Among the crosses JT 90-1 x YSH 401 and YSH 401 x B9 were the best specific combiners with higher mean values. YSH $401 \times$ B9 was a good cross for both NUE and yield. For developing a high yielding cultivar with high NUE, this cross could be utilized in breeding progamme.

The results of the present investigation offered considerable scope for breeding high yielding rapeseed genotypes with high NUE. Variability and correlation revealed that selection would be highly effective for biological yield per plant and NUE. The study throws light on the prospect of developing high performing genotypes from yellow sarson x toria crosses. Good characteristics of toria and yellow sarson could be recombined by recombination and selection. Further research is necessary to study the precise genetic nature of nitrogen use efficiency and to identify genes and to tag them with molecular markers for marker assisted selection.

\section{References}

Al-Jibouri, N. A.; Miller, F.A. and Robinson, H.P. (1958). Genotypic and environmental variances, covariances in an upland cotton cross of interspecific origin. Agron. J. 50: 633-637.

Allard, R.W. (1960). Principles of plant breeding.John Wiley and Sons, Inc. New York.

Baker, R.J. (1978). Issues in diallel analysis. Crop Sci. 18 : 533-36.

Barman, B. (1994). Studies on intra and inter population variability in rapeseed (Brassica campestris L.). M. Sc. Thesis, Assam Agricultural University, Jorhat.

Barua, P. K. (1992). Genetic analysis of yield parameters in varietal hybrids of Indian rapeseed (Brassica campestris L.). Ph. D. Thesis, Assam Agricultural University, Jorhat.

Bouchet A. S, Laperche A., Belaygue C. B., Snowdon R., Nesi N. and Stahl A. (2016). Nitrogen use efficiency in rapeseed. A review. Agron. Sustain. Dev. 36: 38.

Brar, K.S., Yadav, M.S., Mittal, V.P. and Singh, P. (2006). Combining ability for seed yield, its component characters and oil content in toria. Crop Improvement 33(2): 185-189.

Burton, G.W. (1952). Quantitative inheritance of grasses. Proc. $6^{\text {th }}$ Inter. Genet. Cong. 1 : 227-283.

Channa S. A., Tian H., Mohammed M. I., Zhang R., Faisal S., Guo Y., Klima M., Stamm M. and $\mathrm{Hu} \mathrm{S.} \mathrm{(2018).} \mathrm{Heterosis}$ and combining ability analysis in Chinese semiwinter3 exotic accessions of 
rapeseed (Brassica napus L.). Euphytica 214:134.

Cheema, K.L., and Sadaqat, H.A. (2004). Potential and genetic basis of drought tolerance in canola (Brassica napus L.): I. Generation mean analysis for some phonological and yield components. Intl. J. Agric. Biol. 6: 74-81.

Christopher, G.L., Andrew, J.R.; Geraldine, A.C.L.; Clare, J.H.; Jacqueline, B.; Gary, B.; German, C.S. and David, E. (2005). Brassica ASTRA: an integrated database for Brassica genomic research. Nucleic Acids Res., 1; 33: D656-D659.

Dar, Z.A.; Wani, S.A.; Ahmed, I. and Gulzaffar, M.H.K. (2010). Heterosis and combining ability in Brown sarson (Brassica rapa L.). Crusiferae Newsletter. 29: 46-50.

Fageria, N.K. and Baligar, V.C. (2005).Enhancing nitrogen use efficiency in crop plants. Adv. Agron. 88: 97-158.

Falconer, D.S. (1960). Introduction to Quantitative Genetics. Oliver and Boyd, Edinburgh.

Gomez, K.A. and Gomez, A.A. (1984). Statistical procedure for agricultural research. John Wiley and Sons, New York.

Griffing, B. (1956). Concept of general and specific combining ability in relation to diallel crossing system.Aust. J. Biol. Sci. 9: 463-493.

Hiscox, J.D. and Israelstam, G.F (1979). A method for the extraction of chlorophyll from leaf tissue without maceration. Can. J. Bot. 57: 1332-1334.

Jackson, M.L. (1973). Soil chemical analysis. Prentice Hall of India Pvt. Ltd., New Delhi.

Khulbe, R.K.; Pant, D.P. and Rawat, R.S. (1998). Heterosis for yield and its components in Indian mustard. J. Oilseed Res. 15: 227-230.

Klepper, L. and Hageman, R.H. (1969). The occurrence of Nitrate Reductase in apple leaves. Plant. Physiol. 44: 110-114.

Koch, K. K. (2005). Genetic variation and selection response in toria under delayed sowing in rice fallow. M. Sc. Thesis, Assam agricultural University, Jorhat.

Lal R., Tiwari R., Verma O. P. and Solanki I. S. (2018). Genetic evaluation for seed yield and its contributing traits in Brassica rapa (L). var. yellow sarson. The Pharma Innovation Journal, 7(12): 201-203.

Meena H. S., Kumar A., Ram B., Singh V. V., Meena P. D., Singh, B. K., and Singh, D. (2015). Combining ability and heterosis for seed yield and its components in Indian mustard (Brassica juncea L.). J. Agr. Sci. Tech. (2015) Vol. 17: 18611871 .

Misra, A. K. (2012). Genetic variability and correlation studies on germplasm of yellow sarson (B. rapaL. var. yellow sarson) for seed yield and its component traits. Cruciferae Newsletter. 31: 46.

Naheed H., Raziuddin, Farhatullaj, Sohail Q. and Khan N. (2017). Genetic analysis for yield and yield components in Rapeseed. Turkish journal of Agricultural and Natural sciences.4(4): 376-384, 2017.

Nasim, M.; Rahman, L.; Quddus, M.A.and Alan, M.S. (1997). Combining ability and heterosis in Brassica campestris L. Thai Journal of Agricultural Science 30(1): 27-35.

Ofori, A.and Becker, H.C. (2008). Breeding of Brassica rapa for Biogas Production: Heterosis and Combining Ability of Biomass Yield. Bio Energy Research 1(1): 98-104.

Panse, V.G. (1957). Genetic of quantitative characters in relation to plant breeding. Indian J. Genet. 17: 318-329.

Rahman, M.M.; Chowdhury, M.A.Z.; Hossain, M.G.; Amin, M.N.; Muktadir, M.A. and Rashid, M.H. (2011). Gene action for seed yield and yield contributing characters in turnip rape 
(Brassica rapa L.). Journal of Experimental Bioscience 2(2): 67-76.

Raja, K. and Bishnoi, S. (1990). Soil-water plant relationship of rape (Brassica campestris var. toria) genotypes under irrigated and dry condition. Ind. J. Agron.35: 91-98.

Rameeh, V. (2010). Combining ability of quantitative and qualitative traits in rapeseed (Brassica napus) varieties at two nitrogen levels. Crop Breeding Journal, 1(2): 119-125.

Rameeh V. (2017). Hybrid Performance and combining ability analysis in rapeseed using LinexTester mating design. International Journal of Research in Agriculture and Forestry, 4(8): 22-28.

Roy, D. (2012). Biometrical Genetics Analysis of Quantitative Variation. Narosa Publishing House, New Delhi.

Sarma, A. C. (1993). Performance evaluation, genetic variability and phenotypic stability for yield and related characters in a set of rapessed (Brassica campestris L.) varieties and their crosses in $\mathrm{F}_{2}$ generation. M.Sc. Thesis. Assam Agricultural University, Jorhat.

Singh, D. (1973). Diallel analysis for combining ability over environments - II. Indian J. Genet. 33: 469-481.

Singh, D. (1979). Diallel analysis for combining ability over environments. Indian J. Genet. 39: 383-386.

Singh, D.; Mishra, V.K. and Sinha, T.S. (2001).Genetic architecture of yield and its contributing characters in yellow sarson (Brassica campestris L. var. yellow sarson Prain). Indian Journal of Agricultural Research.35(4): 263-266.

Singh, M.; Singh, L, and Srivastava, S.B.L. (2010). Combining ability analysis in Indian mustard (Brassica juncea L.). Journal of Oilseed Brassica. 1(1): 23-27.

Singh,T. and Kumar, R. (2007). Genetic variability and correlation analysis over different environments in toria Brassica rapa L. var. toria. J. of Research. 6 (1): 47- 53.

Sirohi, G.S., Uprety, D.C. and Tomar, O.P.S. (1978). Studies on root growth of wheat varieties. Ind. J. Plant Physiol. 21: 185196.

Stahl, A., Vollrath P., Samans B., Frisch M., Wittkop B. and Snowdon R. J. (2019). Effect of breeding on nitrogen use efficiency-associated traits in oilseed rape. Journal of Experimental Botany, 70 (6): 1969-1986.

Stahl A., Pfeifer M., Frisch M., Wittkop, B. and Snowdon, R. J. (2017). Recent genetic gains in nitrogen use efficiency in oilseed rape. Frontiers in Plant Science. 8: Article 963.

Thurling N. and Das, V. (1979). Genetic control of pre-anthesis development of spring rape (Brassica napus L.). I. Diallel analysis of variation in the field. Aust. J. Agric. Res.30: 251-259.

Venkateswarlu, S. and Singh, R. B. (1981). Combining ability for earliness in pigeonpea. Indian J.Gent. 41: 252-254.

\section{How to cite this article:}

Priyakshee Borpatra Gohain, Smrita Gogoi, Kaushik Das and Purna K. Barua. 2020. Combining Ability for Nitrogen Use Efficiency in a Diallel Cross of Indian Rapeseed (Brassica rapa L.). Int.J.Curr.Microbiol.App.Sci. 9(12): 1746-1760.

doi: https://doi.org/10.20546/ijcmas.2020.912.207 